between the groups, univariate regression analyses were made. In all analyses significance level was set at 0.05 .

Abstract AB0533 - Table 1. Sociodemographic and clinical characteristics according to treatment groups

\begin{tabular}{|c|c|c|c|c|}
\hline Characteristics & Group $1(\mathbb{N}-409)$ & Group $2(N-272)$ & Group $3(\mathrm{~N}-53)$ & Global p-volue \\
\hline femole, $N(S)$ & $37(92.25)$ & 249 (91.55) & $49(92.55)$ & 0.948 \\
\hline Covcosisns, $N(s)$ & $375(105.9 \%)$ & 235 (91.1\%) & $42(8758)$ & 0.029 \\
\hline Age, vears (mentiso) & $4877+146$ & $405+137$ & $45,4+142$ & 60.001 \\
\hline Durston of ditesse, vers iments5) & $12.9+8.4$ & $13.2 \pm 8.0$ & $11.7 \pm 6.6$ & 0.507 \\
\hline Non:mokers, $N($ K) & $145(00.1 \%)$ & و(166.2\%) & $22(66.78)$ & 0.719 \\
\hline 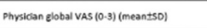 & 0.140 .2 & 0.440 .5 & 0.440 .5 & 6.001 \\
\hline steoal (meantso) & 1.612 .7 (min:0; $\max 8)$ & $29.913 .3(\min : 0 ; \max 19)$ & $2.55 .0(\min 0 ; ; \max 199)$ & 8.001 \\
\hline Inactive disease $\left(S_{4}\right)\left(\mathrm{N}\left(F_{0}\right)\right)$ & $283(88.256)$ & $152(745 \%)$ & $22(78.6 \times)$ & \multirow{3}{*}{$<0.001$} \\
\hline Mid-moderote divesse $(5 \cdot 12)$ (N/SI) & $28(8.70)$ & $45(221.16)$ & $5(17.96)$ & \\
\hline Severe disease $(>12)(N(\mathbb{N}))$ & $10(3.1 \times)$ & $7(3.4 \times)$ & $13.65)$ & \\
\hline \multirow{2}{*}{ 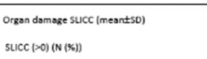 } & $0.5+1.1$ & 0.771 .3 & $1.0 \pm 1.4$ & 0.012 \\
\hline & $119(30.75)$ & $100(3925)$ & $24(4896)$ & 0.010 \\
\hline Aate cutaneous lupus, $N($ S) & $220(57.06)$ & $156(60.95)$ & $35(77.558)$ & 0.059 \\
\hline Chronic cutaneous lupus, $N(x)$ & $51(13.5 \times)$ & $33(12.9 \%)$ & 10(21.7\%) & 0.914 \\
\hline Oral or nossal uketr, $N(x)$ & 91(2335) & $800(30.75)$ & $25(521 \times)$ & $<0.001$ \\
\hline Non-zcarring alopecia, $N(S)$ & $59(1598)$ & $57(23858)$ & $10(50.0 \mathrm{k})$ & $<.001$ \\
\hline Arthretes, $N(x)$ & $255(6.7 \%)$ & $201(76.7 \%)$ & $45(90.05)$ & 8.001 \\
\hline serosinh, $N(x)$ & $7(19.65)$ & $62(23.7 \%)$ & $12(22.115)$ & 0.345 \\
\hline Renas involvement $N(x)$ & $76(20.45)$ & 134 (53.85) & $19(3,25)$ & 80.001 \\
\hline Neurobeki involvement, $N(S)$ & 21 215.7\%) & $24(9.65)$ & $8(18.25)$ & 0.015 \\
\hline \multirow{4}{*}{ 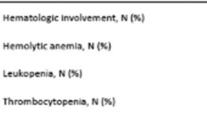 } & $248(63.48)$ & $194(749 \%)$ & $39(81.36)$ & 0.001 \\
\hline & $29(7.4 \times)$ & $41(15.7 \%)$ & $7(1496)$ & 0.002 \\
\hline & $179(67.45)$ & $142(56.85)$ & $33(70.25)$ & 0.002 \\
\hline & $75(1995)$ & $71(28.45)$ & $23(28.5 \mathrm{~s})$ & 0.034 \\
\hline Glucocorticoolds, N(S) & $145(35.5 \%)$ & $211(77.65)$ & $43(81.15)$ & \\
\hline Antimalariak, $N(x)$ & $400(10005)$ & $210(77.25)$ & 3769.851 & \\
\hline Immunossuppressents, $N(\mathbb{*})$ & - & $\begin{array}{c}137(50.45) / 87 \\
(320 \times 5 / 55(202 \times)\end{array}$ & $\begin{array}{c}11(20.8 \%) /(13.25) / 9 \\
(16.96)\end{array}$ & \\
\hline 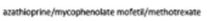 & & & & \\
\hline
\end{tabular}

Results: A total of 824 SLE patients were included, mean age of $47.3 \pm 14.4$ years, $92.3 \%$ female. The mean age at first symptoms was $31.6 \pm 14.1$ and at SLE diagnosis of $34.1 \pm 14.3$ years. On their last assessment, $678(82.3 \%)$ were being treated with antimalarials, $463(56.2 \%)$ glucocorticoids, 343 (41.6\%) immunosuppressants (149 AZA, 99 MM, 67 MTX, 14 cyclosporine, 11 cyclophosphamide, 3 leflunomide), 53 (6.4\%) biologics (32 rituximab, 21 belimumab) and $26(3.2 \%)$ were off medication. The sociodemographic and clinical characteristics according to treatment groups are shown in table 1. Gender distribution was similar across groups. A high prevalence of women, Caucasians, non-smokers, acute cutaneous lupus and arthritis was found in all groups. Patients in group 1 had lower disease activity measured by SLEDAI, less organ damage measured by SLICC and lower physician's global assessment. In group 2 patients were younger and had higher prevalence of renal involvement. Patients in group 3 had higher SLEDAI score and damage, higher prevalence of mucocutaneous, articular, neurologic and hematologic involvement and more use of glucocorticoids.

Conclusions: Almost all SLE patient with established disease were chronically medicated, most with antimalarials and/or glucocorticoids. As expected, group 1 had less severe disease. Patients under immunosuppressants had a higher frequency of renal involvement, which denotes a targeted therapeutic strategy. In routine clinical settings biologics are rarely used, being restricted to patients with very active SLE and multiple clinical manifestations.

Disclosure of Interest: None declared

DOI: 10.1136/annrheumdis-2018-eular.4306

\section{AB0534 PROPORTION OF SJOGREN'S SYNDROME PATIENTS REFERRED TO ORAL SPECIALISTS AT A RHEUMATOLOGY TERTIARY CENTRE AND FACTORS ASSOCIATED WITH THEIR REFERRAL}

G. Levinson ${ }^{1}, \underline{\text { U. Ahmed }}{ }^{1}, \mathrm{C}$. Ciurtin ${ }^{1,2} .{ }^{1}$ UCL; ${ }^{2}$ Department of Rheumatology, UCLH, London, UK

Background: Ideally all patients with Sjögren's Syndrome (SS) and symptoms of mouth dryness should be assessed by an oral specialist (OS) team at 3-6 monthly intervals for optimisation of their treatment for xerostomia and minimisation of the risk of dental loss ${ }^{1}$. However, in reality specialist input is not always offered.

Objectives: To determine the proportion of SS patients at a rheumatology tertiary centre who were referred to OS and evaluate if any factors were associated with referral.
Methods: We retrospectively collected data about 105 patients with primary or secondary SS who attended outpatient clinics in October - November 2016, including duration of symptoms and years since diagnosis, presence of SS associated symptoms, medications trialled to date, and serological, imaging and histological patient features. We have also assessed proportion of patients referred to OS, as well as the medication recommended by the OS. $p<0.05$ was considered significant.

Results: In our cohort, $58.1 \%$ of SS patients were referred to an OS. We compared patient demographics and various disease features (table 1) in SS patients who were referred to OS and those who were not.

Abstract AB0534 - Table 1

\begin{tabular}{|c|c|c|c|}
\hline & $\begin{array}{l}\text { SS patients seen } \\
\text { by oral } \\
\text { specialists } \\
n=61\end{array}$ & $\begin{array}{l}\text { SS patients never } \\
\text { referred to oral } \\
\text { specialists } \\
n=44\end{array}$ & $P$ value \\
\hline Gender F (\%) & 93 & 98 & 0.17 \\
\hline Age (years) mean $\pm S D$ & $60.1 \pm 16.7$ & $50.1 \pm 15.3$ & 0.023 \\
\hline $\begin{array}{l}\text { Disease duration } \\
\text { (years) mean } \pm S D \text { ) }\end{array}$ & $9.7 \pm 7.9$ & $7.4 \pm 5 / 2$ & 0.57 \\
\hline $\begin{array}{l}\text { Symptoms duration } \\
\text { (years) mean } \pm S D \text { ) } \\
\text { Medication }\end{array}$ & $11.0 \pm 8.47$ & $10.0 \pm 5.80$ & 0.2 \\
\hline $\begin{array}{l}\text { Oral prednisolone } \\
\mathrm{N}(\%)\end{array}$ & 13.1 & 27.3 & 0.069 \\
\hline $\begin{array}{l}\text { Hydroxychloroquine/Chroloquine } \\
\mathrm{N}(\%)\end{array}$ & 65.6 & 68.2 & 0.78 \\
\hline $\begin{array}{l}\text { Azathioprine } \\
\mathrm{N}(\%)\end{array}$ & 12.5 & 15.4 & 0.75 \\
\hline $\begin{array}{l}\text { Methotrexate } \\
\mathrm{N}(\%)\end{array}$ & 8.82 & 24 & 0.12 \\
\hline $\begin{array}{l}\text { Saliva substitutes } \\
\mathrm{N}(\%) \\
\text { Associated Symptoms }\end{array}$ & 59.5 & 32 & 0.034 \\
\hline $\begin{array}{l}\text { Oral dryness (VAS>5/10) } \\
N(\%)\end{array}$ & 95.1 & 72.7 & 0.0012 \\
\hline $\begin{array}{l}\text { Glandular enlargement } \\
\mathrm{N}(\%)\end{array}$ & 27.9 & 13.6 & 0.082 \\
\hline $\begin{array}{l}\text { Maximum ESSDAI score } \\
\text { Median (interquartile range) } \\
\text { Serology, Histology and Imaging }\end{array}$ & $7(4-12)$ & $6(4-10.75)$ & 0.36 \\
\hline $\begin{array}{l}\text { Anti Ro antibodies } \\
\mathrm{N}(\%)\end{array}$ & 79.2 & 78.4 & 0.92 \\
\hline $\begin{array}{l}\text { Anti La antibodies } \\
\mathrm{N}(\%)\end{array}$ & 61.4 & 58.1 & 0.77 \\
\hline $\begin{array}{l}\text { Positive salivary gland biopsy } \\
\mathrm{N}(\%)\end{array}$ & 100 & 83.3 & 0.20 \\
\hline $\begin{array}{l}\text { Ultrasound scan of salivary } \\
\text { glands showing definite features } \\
\text { of SS } \\
\mathrm{N}(\%)\end{array}$ & 86.4 & 66.7 & 0.38 \\
\hline
\end{tabular}

The parameters that correlated with the referral to OS were oral dryness (VAS $>5$ / 10) $(p=0.0012)$ and the use of saliva substitutes $(p=0.034)$.

The most common OS treatment recommendations were for use of Duraphat $5000 \mathrm{ppm}(50.8 \%)$, Salivix pastilles $(44.3 \%)$, mouth wash $(41 \%)$ and Glandosane $(36 \%)$, apart from frequent sips of water recommended in all patients.

Conclusions: $58.1 \%$ of SS patients at a tertiary rheumatology centre were referred to OS. The factors that correlated with onward referral to the OS from the Rheumatologist in SS patients were oral dryness and treatment with saliva substitutes. This suggests that Rheumatologists adequately treat xerostomia and refer to OS appropriately when patients remain symptomatic. Further research is needed to assess whether there is a difference in outcome for patients referred to an OS versus those who are not.

\section{REFERENCE:}

[1] Price E, Rauz S, Tappuni A, Sutcliffe N, Hackett K, Barone F, et al. The British Society for Rheumatology guideline for the management of adults with primary Sjögren's Syndrome. Rheumatology 2017;56(10):1828-1828.

Disclosure of Interest: None declared

DOI: 10.1136/annrheumdis-2018-eular.2272 